\title{
KEARIFAN LOKAL MASYARAKAT KEMUKIMAN BAMBI DALAM MENGOLAH TANAMAN BINAHONG (Anrederaordifolia)SEBAGAI TANAMAN OBAT
}

\author{
Ervina Dewi ${ }^{1}$, Rahmi Agustina $^{2}$, Miftahul Husna ${ }^{3}$ \\ 1, 2 Program Studi Pendidikan Biologi FKIP Universitas Jabal Ghafur \\ 1ervina_dewi@unigha.ac.id \\ 2ami.binti.asyar@unigha. ac.id
}

\begin{abstract}
ABSTRAK
Pemanfaatan tanaman binahong (Anredera cordifolia) sebagai tanaman obat tradisional oleh masyarakat di Kemukiman Bambi Kecamatan Peukan Baro Kabupaten Pidie merupakan salah satu bentuk kearifan lokal yang harus dipertahankan. Informasi ini guna memperkaya data bioekologi sehingga dapat dijadikan acuan dalam pengelolaan dan pengolahan tanaman Binahong berbasis kesejahteraan masyarakat dan kelestarian lingkungan. Oleh karena itu penelitian ini dilakukan untuk mengkaji kearifan lokal masyarakat di Kemukiman Bambi Kecamatan Peukan Baro Kabupaten Pidie dalam mengolah tanaman binahong sebagai obat tradisional. Metode yang digunakan adalah wawancara secara mendalam dan pengamatan langsung di 3 (tiga) desa yaitu Blang Raya, Lueng Mesjid, dan Dayah Teungku Kemukiman Bambi Kecamatan Peukan Baro Kabupaten Pidie. Wawancara dilakukan untuk menggali informasi kearifan lokal masyarakat dalam menyiapkan obat tradisional. Hasil penelitian memperlihatkan bahwa masyarakat yang menjadi responden dalam penelitian ini memiliki kearifan lokal yang sudah turun menurun dibudayakan terutama dalam mempreparasi obat-obat tradisional khususnya berbahan dasar Binahong. Metode preparasi yang paling banyak digunakan adalah metode rebus dengan alasan mudah untuk dikerjakan dan banyak kandungan zat dalam tanaman Binahong yang terlarut akibat perebusan.
\end{abstract}

Kata Kunci: Tanaman Binahong (Anredera cordifolia), Kearifan Lokal, Metode Preparasi obat

Tradisional

\section{LATAR BELAKANG}

Kearifan lokal adalah kepribadian budaya sebuah bangsa yang menyebabkan bangsa tersebut mampu menyerap, bahkan mengolah kebudayaan yang berasal dari luar/bangsa lain menjadi watak dan kemampuan sendiri. Kearifan lokal juga dikenal sebagai pandangan hidup dan ilmu pengetahuan serta berbagai strategi kehidupan yang berwujud aktivitas yang dilakukan oleh masyarakat lokal dalam menjawab berbagai masalah dalam pemenuhan kebutuhan sehari-hari (Wibowodan Gunawan, 2015:17).

Kearifan lokal dalam masyarakat merupakan warisan yang diwariskan secara turun menurun dari generasi kegenerasi. Kearifan lokal sebagai suatu pengetahuan yang ditemukan oleh masyarakat lokal tertentu melalui kumpulan pengalaman dalam mencoba dan diintegrasikan dengan pemah aman terhadap budaya dan keadaan alam suatu tempat. Salah satu wilayah di Kabupaten Pidie yang memiliki berbagai kearifan lokal dikalangan masyarakatnya adalah Kemukiman Bambi.

Kemukiman Bambi merupakan salah satu kemukiman yang terletak di Kecamatan Peukan Baro Kabupaten Pidie. Kemukiman Bambi terdiridari 8 (Delapan) desa yaitu: DayahTengku, Jurong Raya, BaleeRastrong, Blang Raya, Lueng Mesjid, TeungohBaroh, MeehagudanDayahSukon. Ke- delapan desa di Kemukiman Bambi memiliki kearifan lokal berupa mahir dalam menyiapkan berbagai obat tradisional untuk kebutuhan sehari-hari. Konsep Back To Nature dalam bidang pengobatan berbagai jenis penyakit sudah sangat lama ditekuni oleh sebagian besar masyarakat Kemukiman Bambi 
tersebut. Masyarakat lebih memilih mengkonsumsi obat-obatan dari bahan alami yang relatif lebih aman dibandingkan obatobatan dari bahan kimia sintetik. Pengobatan tradisional yang berasal dari tanaman merupakan manifestasi dari partisipasi aktif masyarakat dalam menyelesaikan problematika kesehatan dan telah diakui peranannya oleh berbagai bangsa dalam meningkatkan derajat kesehatan masyarakat. World Health Organization (WHO) merekomendasi penggunaan obat tradisional termasuk obat herbal dalam pemeliharaan kesehatan masyarakat, pencegahan dan pengobatan penyakit, terutama untuk kronis, penyakit degeneratif dan kanker (Setiawati, 2016).

Hasil observasi memperlihatkan bahwa masyarakat menggunakan berbagai tanaman sekitar yang berkhasiat obat untuk mengobati berbagai jenis penyakit. Tanaman tersebut juga dijadikan sebagai bumbu masak seperti jahe, sereh, daun pandan, daun salam, bawang putih dan lain sebagainya. Obat tradisional yang diramu oleh masyarakat sekitar dikenal dengan jamu. Biasanya jamu digunakan dalam pengobatan komplementer alternatif yaitu pengobatan non konvensional yang bertujuan untuk upaya preventif, promotif, dan kuratif dalam meningkatkan derajat kesehatan masyarakat perkotaan dan pedesaan (Ahmad,2012). Salah satu obat tradisional yang diramu oleh masyarakat di Kemukiman Bambi adalah obat tradisional berbahan dasar tanaman Binahong (Anrederacordifolia).

Tanaman binahong termasuk kedalam family Basellaceae adalah tanaman berpotensi sebagai obat yang dapat mengatasi berbagai jenis penyakit. Tanaman ini berasal dari dataran Cina dan menyebarke Asia Tenggara dan merupakan salah satu tanaman obat yang mempunyai potensi besar kedepan untuk diteliti, karena dari tanaman ini masih banyak yang perlu digali sebagai bahan fito farmaka. Terutama untuk mengungkapkan khasiat dari bahan aktif yang dikandungnya. Berbagai pengalaman yang ditemui di masyarakat, tanaman binahong dapat dimanfaatkan untuk membantu proses penyembuhan berbagai penyakit (Manoi, 2009).

Berbagai hasil penelitian yang telah dilakukan sebelumnya, tanaman binahong berpotensi sebagai anti bakteri (Fitriyahet al., 2013) seperti menekan pertumbuhan bakteri Acne vulgaris yang menyebabkan tumbunya jerawat (Anwar dan Soleha, 2016), anti kolesterol (Anggarinidan Ali, 2017), penyembuhan pada luka sayat (Amita et al., 2017) dan hepatoprotektif (Orbaniyah dan Kartyanto, 2008).

Berdasarkan sejarah ekologi, diketahui bahwa sejak zaman dahulu, berbagai etnik di Indonesia termasuk wilayah Aceh telah mengenal teknik pengobatan tradisional yang asal dari hewan (Partasasmita et al., 2016) dan tumbuhan disekitar pekarangan rumah untuk mengobati berbagai penyakit baik penyakit luar maupun penyakit dalam (Pical, 2013). Namun, seiring dengan perubahan zaman, terjadi berbagai perubahan pada ekosistem dan perkembangan ekonomi pasar, telah menyebabkan berbagai perubahan terhadap sistem sosial penduduk di Indonesia.Hal tersebut termasuk kian tergerusnya pengetahuan lokal dan budaya pemanfaatan dan pengelolaan tumbuhan yang dijadikan obat secara tradisional oleh masyarakat lokal, bahkan dimungkinkan pula dapat terjadi kepunahan (Kinho et al. 2011).

Oleh karena itu, studi tentang kearifan lokal masyarakat setempat tentang metode prepreparasi tanaman berkhasiat obat khususnya tanaman binahong di Kemukiman Bambi Kecamatan Peukan baro Kabupaten Pidie sangat penting untuk dilakukan. Masyarakat di Kemumikan Bambi dikenal masih memanfaatkan tumbuhan obat guna pengobatan berbagai penyakit atau gangguan kesehatan.

\section{METODE PENELITIAN Lokasi Penelitian dan Pemilihan Responden}

Penelitian ini bertempat di Kemukiman Bambi kecamatan Baro Kabupaten Pidie yang terdiri dari 8 (delapan) desa yaitu Dayah Tengku, Jurong Raya, Balee Rastrong, Blang Raya, Lueng Mesjid, Teungoh Baroh, Mee 
Hagu dan Dayah Sukon. Lokasi penelitian dipilih secara purposive sampling yang terdiri dari 3 (tiga) desa yaitu: Blang Raya, Lueng Mesjid, dan Dayah Teungku. Pemilihan lokasi penelitian berdasarkan banyaknya jumlah masyarakat yang memanfaatkan tanaman binahong sebagai obat tradisional. Lokasi penelitian dapat dilihat pada Gambar 1.

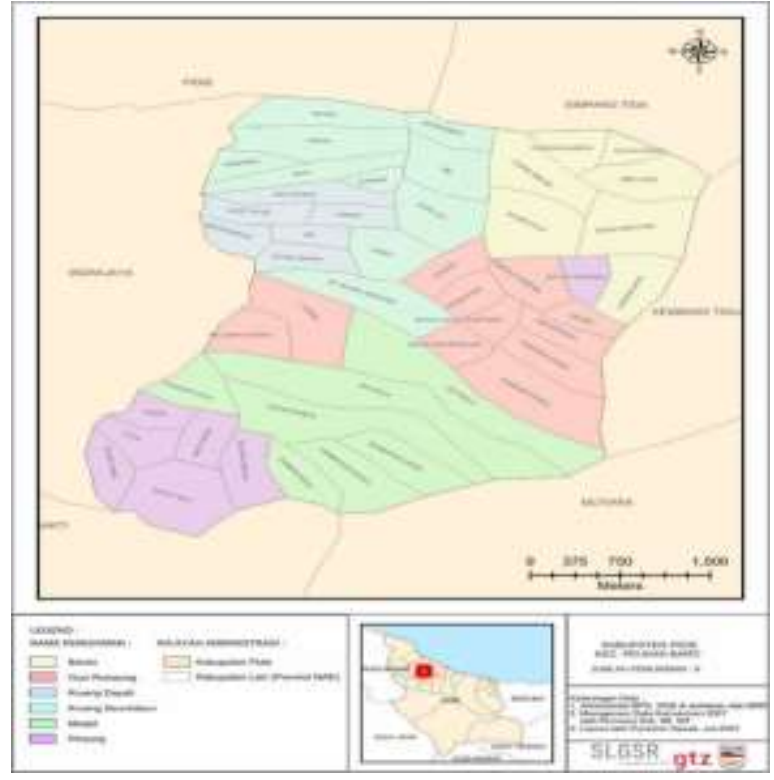

Responden pada penelitian dipilih secara purposive sampling, yaitu masyarakat yang mengenal dan memanfaatkan tanaman binahong (Anredera cordifolia) sebagai obat tradisional. Responden berjumlah 15 orang untuk setiap desa, sehingga total responden adalah 45 responden.

\section{Prosedur Kerja}

Pengambilan data dilakukan dengan metode wawancara secara mendalam dan pengamatan langsung terhadap kehidupan masyarakat di Kemukiman Bambi Kecamatan Peukan Baro Kabupaten Pidie. Wawancara dilakukan terhadap 15 responden dalam tiap desa yan menjadi lokasi penelitian. Total responden yang diwawancarai sebanyak 45 responden. Wawancara dengan setiap responden dilakukan untuk menggali informasi kearifan lokal masyarakat dalam menyiapkan obat tradisional.

\section{Analisis Data}

Data hasil penelitian berupa kearifan lokal masyarakat di Kemukiman Bambi Kecamatan Peukan Baro Kabupaten Pidie dianalisis secara deskriptif dan disajikan dalam bentuk tabel.

\section{HASIL DAN PEMBAHASAN}

Masyarakat desa Blang Raya, Lueng Mesjid, dan Dayah Teungkudi Kemukiman Bambi Kecamatan Peukan Baro Kecamatan Pidie memiliki berbagai bentuk kearifan lokal. Kearifan lokal merupakan suatu kepribadian budaya sebuah bangsa yang dikenal sebagai pandangan hidup dan ilmu pengetahuan serta berbagai strategi kehidupan yang berwujud aktivitas yang dilakukan oleh masyarakat lokal dalam menjawab berbagai masalah dalam pemenuhan kebutuhan sehari-hari (Wibowo dan Gunawan, 2015:17). Salah satu kearifan lokal yang sangat membudaya ditengah masyarakat adalah kearifan lokal dalam menyiapkan obat tradisional (metode preparasi) khususnya berbahan dasar tanaman binahong (Tabel 1).

Tanaman Binahong digunakan sebagai obat tradisional karena mengandung berbagai senyawa metabolit yang bermanfaat, berupa flavonoid, alkaloid, terpenoid atau steroid, dan saponin yang telah terbukti berkhasiat obat (Astuti, 2012). Berbagai hasil penelitian sebelumnya memperkuat pemanfaatan tanaman binahong sebagai obat.

Beberapa penyakit yang dapat disembuhkan dengan menggunakan tanaman binahong adalah: kerusakan ginjal, diabetes, pembengkakan jantung, muntah darah, tifus, stroke wasir, rhematik, pemulihan pasca operasi, pemulihan pasca melahirkan, radang usus, melancarkan dan menormalkan peredaran dan tekanan darah, sembelit, sesak napas, sariawan berat, pusing-pusing, sakit perut, menurunkan panas tinggi, menyuburkan kandungan, maag, asam urat, keputihan, pembengkakan hati, meningkatkan vitalitas dan daya tahan tubuh (Manoi 2009).

Tanaman binahong juga berpotensi sebagai anti bakteri (Fitriyah et al., 2013) 
seperti menekan pertumbuhan bakteri Acne vulgaris yang menyebabkan tumbunya jerawat (Anwar dan Soleha, 2016), anti kolesterol (Anggarini dan Ali, 2017), penyembuhan pada luka sayat (Amita et al., 2017) dan hepatoprotektif (Orbaniyah dan Kartyanto, 2008).

Tabel 1. Kearifan Lokal Masyarakat di Kemukiman Bambi dalam Menyiapkan Obat Tradisional Berbahan Dasar Tanaman Binahong

\begin{tabular}{|c|c|c|c|}
\hline No & Metode Preparasi & Jumlah Respoeden & Persentase ( 86 ) \\
\hline I & Jus & 1 & 2222 \\
\hline 2 & Rebos & 23 & 51.111 \\
\hline 3 & Sedab & 1 & 2222 \\
\hline 4 & Makan Lanpoung & 9 & 20 \\
\hline 5 & Dejadikan Pil & 2 & 4.444 \\
\hline 6 & Tumbek dan dooles & 9 & 20 \\
\hline \multicolumn{2}{|r|}{ Jumlah } & 45 & 100 \\
\hline
\end{tabular}

Sumber: Hasil Wawancara Responden Di Kemukiman Bambi Kecamatan Peukan Baro Kabupaten Pidie, 2018.

Tabel 1 memperlihatkan bahwa masyarakat di Kemukiman Bambi Kecamatan Peukan Baro Kabupaten Pidie memiliki kearifan dalam menyiapkan (metode preparasi) obat tradisional berbahan dasar tanaman binahong. Metode preparasi yang digunakan oleh masayarakat bervariasi sesuai dengan jenis penyakit yang akan diobati. Terdapat 6 metode yang digunakan untuk menyiapkan obat tradisional yaitu dijadikan jus, direbus, diseduh, dimakan langsung, dijadikan pil dan ditumbuk lalu dioles.

Metode preparasi yang paling banyak digunakan oleh masyarakat di Kemukiman Bambi yaitu dengan cara direbus. Metode preparasi dengan cara direbus dipercaya oleh masyarakat sebagai metode pengolahanyang sangatmudah dan sangat efektif karena masyarakat pada umunya lebih suka tumbuhan berkhasiat obat tersebut diolah menjadi air rebusan dibandingkan mengkonsumsi secara langsung. Proses perebusan menjadikan tanaman binahong matang sehingga lebih aman dikonsumsi dan mengurangi rasa pahit bila dibandingkan dengan dilalap atau dimakan langsung. Selain itu, proses penyembuhannya lebih cepat karena langsung diproses dalam metabolisme tubuh (Due, 2013).

Metode preparasi dengan cara direbus juga dipercaya akan mengeluarkan lebih banyak kandungan kimia dibandingkan dengan cara yang lainnya. Menurut Syah et al. (2014) proses perebusan dapat mengeluarkan zat yang terkandung pada tumbuhan dibandingkan dengan cara dibakar. Proses perebusan akan meninggikan suhu larutan. Semakin bahwa semakin tinggi temperatur maka kelarutan suatu zat semakin besar. (Voight, 1994). Hasil penelitian Sari et al. (2015) juga mendukung penelitian ini, bahwa cara pengolahan tumbuhan obat yang paling banyak digunakan oleh masyarakat Suku Dayak Jangkang Tanjung Di Desa Ribau Kecamatan Kapuas Kabupaten Sanggau adalah dengan cara direbus.

Metode lain yang digunakan oleh masyarakat adalah metode makan langsung (20\%) dan Tumbuk dan oles (20\%). Metode preparasi dengan makan langsung dilakukan dengan caraCara pemakaian ini dilakukan dengan memakan langsung bagian tumbuhan obat yang berkhasiat (Nisyapuri et al., 2018). Daun binahong dijadikan lalapan oleh sebagian masyarakat Kemukiman Bambi. Mengkonsumsi tanaman binahong mentahmentah dipercaya mampu menjaga khasiat dan manfaat yang terkandung di dalam daunnya. Khasiat dan manfaat tersebut utuh masuk ke tubuh tanpa terbuang sia-sia saat dimakan mentah-mentah dibandingkan dengan diolah terlebih dahulu.

Metode preparasi tumbuk dan oles merupakan penggunaan tanaman binahong untuk pengobatan luar, biasanya identik dengan mengobati luka. Oleh masyarakat di Kemukiman Bambi digunakan untuk menghilangkan jerawat dan flek hitam pada wajah. Sesuai dengan penelitian sebelumnya, tanaman binahong berpotensi sebagai antibakteri (Fitriyah et al., 2013) seperti menekan pertumbuhan bakteri Acne vulgaris yang menyebabkan timbulnya jerawat (Anwar dan Soleha, 2016).

Metode preparasi dengan teknik penyeduhan sangat jarang dilakukan oleh masyarakat $(2,22 \%)$, demikian juga dijadikan 
pil $(4,44 \%)$. Berdasarkan hasil wawancara, metode preparasi dengan cara penyeduhan membutuhkan waktu yang lama untuk mengolah tanaman binahong hingga siap digunakan. Sebelum diseduh, terlebih dahulu daun binahong dikeringakan sampai benarbenar kering. Seteleh kering ditumbuh hingga halus. Serbuk daun binahong baru siap diseduh atau dimasukan dalam kapsul.

Metode preparasi dengan teknik penyeduhan dan dijadikan pil jarang dilakukan karena minimnya pengetahuan bahwa proses pengeringan tanaman binahong sebelum diseduh dan dijadikan pil mampu mengurangi rasa pahit akibat kandungan alkaloid. Hasil penelitian Dwigustine (2017) telah membuktikan bahwa lama pengeringan mampu mengurangi rasa pahit pada teh herbal berbahan dasar binahong. Hal ini disebabkan oleh sedikitnya kandungan alkaloid.Hasil uji organoleptik juga memperlihatkan bahwa panelis lebih menyukai teh herbal berbahan dasar binahong yang dikeringkan dengan suhu tinggi $(60 \mathrm{oC})$.

\section{KESIMPULAN}

Berdasarkan hasil penelitian dapat disimpulkan bahwa: Masyarakat di Kemukiman Bambi Kecamatan Peukan Baro Kabupaten Pidie telah memiliki kearifan lokal yang terus dibudayakan hingga saat ini terutama dalam hal penyiapan obat tradisional. Metode preparasi obat tradisional berbahan dasar Binahong yang dipilih masyarakat pada umumnya adalah merebus (51\%) dan diikuti dengan cara ditumbuh dan oles $(20 \%)$.

\section{DAFTAR PUSTAKA}

Ahmad, A.F. 2012.Analisis Penggunaan Jamu Untuk Pengobatan Pada Pasien Di Klinik Saintifikasi Jamu Hortus Medicus Tawangmangu. Depok: Universitas Indonesia.

Amita,K., Ummu Balqis dan Cut Dahlia Iskandar. 2017. Gambaran Histopatologi Penyembuhan Luka
Sayat pada Mencit (Mus musculus) Menggunakan Ekstrak Daun Binahong (Anredera cordifolia (Tenore) Steenis). JIMVET. 01(3): 584-591.

Angraini, D. I. dan M. Mufti Ali, 2017. Uji Aktivitas Antikolesterol Ekstrak Etanol Daun Binahong (Anredera cordifolia (Ten) Steenis) Secara In Vitro. Jurnal Ilmiah Kesehatan, 9(1).

Anwar, T.M dan T. U. Soleha. 2016. Manfaat Daun Binahong (Anredera cordifolia) sebagai Terapi Acne Vulgaris. MAJORITY I Volume 5 (5)

Astuti, S.M. 2012. Skrining Fitokimia dan Uji Aktifitas Antibiotika Ekstrak Etanol Daun, Batang, Bunga dan Umbi Tanaman Binahong (Anredera cordifolia (Ten) Steenis). Artikel Ilmiah. Fakulti Kejuteraan Kimia dan Sumber Asli (Bioproses). Universiti Malaysia Pahang. Malaysia.

Fitriyah, N., M. Purwa K., M. Afi f Alfi yanto, Mulyadi, Nila Wahuningsih dan Joko Kismanto. 2013. Obat Herbal Antibakteri Tanaman Binahong.Jurnal KesMaDaSka.

Kinho J, Arini DID, Tabba S, Kama H, Kafiar Y, Shabri S, Karundeng MC. 2011. Tumbuhan obat tradisional di Sulawesi Utara.Jilid 1. Manado. Balai Penelitian Kehutanan Manado Badan Penelitian dan Pengembangan Kehutanan Kementerian Kehutanan.

Manoi, F. 2009. Binahong (Anredera cordifolia) SebagaiObat.Warta Penelitian dan Pengembangan Tanaman Industri. 15(1):3-4.

Partasasmita R, Iskandar J. Malone N. 2015. Karangwangi people's (South Cianjur, West Java, Indonesia) local knowledge of species, forest 
utilization and wildlife conservation. Biodiversitas 17: 154-161.

Pical JM. 2013. Pemanfaatan tumbuhan sebagai obat tradisional oleh masyarakat Kampung Isenebuai Distrik Rumberpon Kabupaten Teluk Wondama. [Skripsi]. Jurusan Kehutanan Fakultas Kehutanan Universitas Negeri Papua, Manokwari.

Sari, A., Riza Linda, dan Irwan Lovadi. 2015. Pemanfaatan Tumbuhan Obat Pada Masyarakat Suku Dayak Jangkang Tanjung Di Desa Ribau Kecamatan Kapuas Kabupaten Sanggau. Protobiont Vol. 4 (2) : 1-8

Setiawati, A. (2016). "The inhibition of Typhonium flagelliforme Lodd.Blume leaf extract on COX-2 expression of WiDr colon cancer cells" 6, 3, February Elsevier Asian Pasific Journal of Tropical Biomedicine.

Syah, J, Usman FH, \& Yusro, F,. 2014. Studi Etnobotani Tumbuhan Obat Yang Dimanfaatkan Masyarakat Dusun
Nekbare Desa Babane Kecamatan Samalantan Kabupaten Bengkayang. Jurnal Hutan Lestari.Vol. 2, no. 3 : 419-426.

Voight, R,. 1994.Buku Pelajaran Teknologi Farmasi. Edisi Kelima. Yogyakarta: Gadjah Mada University Press.

Wibowo, Agus\&Gunawan.2015. Pendidikan Karakter Berbasis Kearifan Lokal di Sekolah.Yogyakarta:

PenerbitPustakaBelajar. 